\title{
ESTIMATION OF THE ECONOMIC LOSSES POTENTIAL DUE TO UNDERWEIGHT TODDLERS IN INDONESIA IN 2013
}

\author{
Brigitte Sarah Renyoet ${ }^{{ }^{*}}$ \\ ${ }^{1}$ Universitas Kristen Satya Wacana, Salatiga, Indonesia \\ *E-mail: brigitte.sarah@yahoo.com
}

\begin{abstract}
Millions of children and adolescents in Indonesia today still show a high number of premature death in children who are moderately malnourished and severely malnourished. The research objective was to calculate the estimated economic losses potential due to underweight among toddlers in Indonesia. This was a descriptive research by analyzing secondary data of nutritional status and socio-economic indicators in 2013 from the Indonesian Ministry of Health and Central Statistical Agency. The formula to calculate potential economic loss is based on Konig's formula (1995) and the correction factor from research by Horton (1999). The results showed that the average economic loss in 32 provinces in Indonesia is approximately IDR 93 billion - IDR 417 billion, which seen from the GRDP percentage, the economic loss due to a decrease in productivity amounted to $2 \%$ and $9 \%$ or about $0.1-0.7 \%$ of the average GRDP of the provinces in Indonesia. Nationally, economic losses due to low productivity in underweight toddlers reach IDR 3,054 billion - IDR 13,746 billion (0.04- $0.2 \%$ ) of Indonesia's total GDP. The results of this study are expected to show that the importance of this issue was handled and can assist the government in planning for health and nutrition programs targeted to human resources in Indonesia qualified and productive.
\end{abstract}

Keywords: malnutrition, children, economic losses

\section{INTRODUCTION}

The risk of death rises sharply due to the increasing problems of malnutrition which is increasingly difficult to handle. According to the report by United Nations Children's Fund (Unicef, 2013), there are 101 million toddlers in 2011 in many parts of the world experienced nutritional problems of underweight. Toddlers belong to the group that prone to health and nutritional problems. Malnutrition is responsible for health status. The health consequences of overnutrition contribute to an estimated four million deaths, while undernutrition explains around $45 \%$ of deaths among children under five (Unicef, 2018).

Some examples of these malnutrition problems, such as what happened in Malawi. The main contributor to the increasing health costs in Malawi is child mortality associated with malnutrition, which is improvidence for the country. Between 2008 and 2012, around 23\% of all child deaths in Malawi "directly related with malnutrition" (African Union Commission \& World Food Programme, 2015). The results of Kalsum and Jahari's research (2013), questioned mothers with less nutritional status who had greater malnourished children. Moreover, overweight mothers are less likely to have malnourished children. The number of samples in the study were as 2213 of underfive children. The analysis showed that $36.6 \%$ of underfive children were stunting (H/A), 19.6\% of underfive children were underweight (W/A) and $17.3 \%$ wasting $(\mathrm{W} / \mathrm{H})$. There are $80 \%$ of the City and District have malnutrition prevalence least not yet achieved the MDG's targets ranged from 15.9 to $26.3 \%$ (Kalsum and Jahari, 2015).

Based on the processed data of Basic Health Survey (RISKESDAS) in 2013, the prevalence of moderate and severe underweight toddler in Indonesia was respectively, $20.3 \%$ and $18.1 \%$ with the general picture of underweight prevalence reached up to $38.4 \%$ in Indonesia. Based on the report by Frontier Economics (Frontier economics, 2017), it was estimated that the malnourished children harming the economy of Papua New Guinea (PNG) as much as US\$ 508 million per 2015-2016 financial year (2.81\% of its annual GDP) through three main way. The first way was productivity losses from the labor reduction due to the increased child mortality, estimated at US\$ 
46 million dollar ( $0.26 \%$ from the GDP); second was potential income and productivity losses from poor physical status and decrease the cognitive function, estimated at US\$459 million $(2.54 \%$ of the GDP); and losses due to the increasing spending for health care in treating diseases related to childhood malnutrition, estimated at US\$ 3 million $(0.02 \%$ of the GDP).

The first two years after birth is the golden period, which the time when the brain cells are experiencing optimal growth and development (Hadi, 2005). Poor nutrition at the age of 2 years and under can reduce the intelligence level of children at a later age. Malnutrition can result in permanent structural and functional changes in the brain (Baker-Henningham and GranthamMcGregor, 2009). According to Azwar (2004) and BAPPENAS (2019), in general, it can be said that economic improvement is the impact of reduced numbers of malnourished persons which related to the reduced costs due to death and illness, while the other side is an increased productivity due to better health and nutrition conditions.

Some of the economic benefits gained as a result of the nutritional status improvement are reduced infant and toddlers' mortality, reduced costs for neonates, toddler, and toddlers care. Increased productivity due to a reduced number of children with malnutrition and the increased intellectual ability reduced costs due to chronic disease and increased "intergeneration" benefits by improving the quality of health. Based on the background of various cases above as well as the resulting impact due to underweight, the researcher was interested to conduct a research related to the estimation of economic losses potential due to underweight toddlers in Indonesia in 2013.

\section{METHOD}

This was a descriptive research carried out by analyzing secondary data from Health Research and Development Agency (microdata from The Indonesian Basic Health Survey (Riset Kesehatan Dasar (RISKESDAS 2013), Ministry of Health of Republic of Indonesia (Kementerian Kesehatan (KEMENKES) RI, 2013) and Central Statistics Agency (BPS, 2013; 2014)
The data were: (1) toddlers characteristics in Indonesia (age, sex, nutritional status data or Z-score (weight/age) of toddlers, total underweight toddlers aged 0-59 months) which obtained from the RISKESDAS report in 2013; (2) 2013 data of population characteristics by province (number of births, gender and age group) from Central Statistics Agency (CSA / BPS) and the Ministry of Health; and (3) data of labor wages/salaries (data on net wages/incomes of workers by province and main employment) from Central Statistics Agency (CSA / BPS) in 2013.

The data was processed with the Microsoft Excel program. The stages of calculation formula used to calculate the amount of potential economic losses due to problems of underweight toddlers were Konig formula (Aries and Martianto, 2006) and the correction factor (Horton, 1999). This Konig formula was used to calculate the economic value of a child who started to work:

$$
F V_{[r, t]}=P_{0}(1+r)^{t}
$$

$$
\begin{aligned}
\mathrm{FV}[\mathrm{r}, \mathrm{t}]= & \text { Income in the productive age }(15-64 \\
& \text { years old }) \\
\mathrm{P} 0 & =\text { Wage/salary } 2013 \\
\mathrm{r} & =\text { Discount rate } \\
\mathrm{t} & =\text { Years of productive life period }
\end{aligned}
$$

The following formula was used to calculate the economic value of a child until retirement:

$$
F V A_{[r, t]}=\frac{\left(F V_{[r, t]}\right)\left[(1+r)^{t}-1\right]}{r}
$$

$$
\begin{aligned}
\mathrm{FVA}_{[\mathrm{r}, \mathrm{t}]}= & \text { Economic value until retirement period } \\
\mathrm{FV}_{[\mathrm{r}, \mathrm{t}]}= & \text { Income in the productive age }(\mathrm{e}, \mathrm{g} \\
& \left.15^{\text {th }} \text { year }\right) \\
\mathrm{r} & =\text { Discount rate } \\
\mathrm{t} & =\text { Years of productive life period }
\end{aligned}
$$

The following formula was used to calculate the economic potential of a child at 0 years old:

$$
P V_{[0]}=\frac{F V A_{[r, t]}}{(1+r)^{t}}
$$

$\mathrm{PV}_{[0]}=$ Economic potential of a child at 0 years 


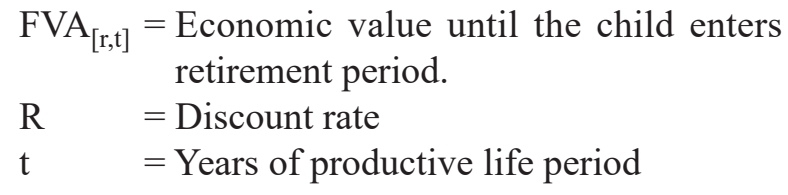

The following formula was used to calculate the amount of productivity lost due to underweight:

$$
\begin{aligned}
& \mathrm{P}_{\mathrm{PEM}}=\text { Prev } \times \Sigma \mathrm{BL} \times \mathrm{PV}_{[0]} \\
\mathrm{P}_{\mathrm{PEM}}= & \text { Lost economic potential due to an } \\
& \text { underweight problem } \\
\mathrm{Prev} \quad= & \text { Underweight prevalence } \\
\Sigma \mathrm{BL}= & \text { Number of births } \\
\mathrm{PV} & =\text { Economic potential of a child at } 0 \text { years } \\
& \text { old }
\end{aligned}
$$

Correction factors (Horton, 1999) were used to calculate the potential economic losses due to underweight after being corrected, which stated that in actual conditions, such children and toddlers can still recover and have less than $100 \%$ productivity. Children who have the history of malnutrition are predicted to experience $2-9 \%$ productivity loss. Therefore, the calculated loss costs do not come from $100 \%$ unproductive children due to underweight. The following formula was used:

$$
\mathrm{P}=\mathrm{f}_{(\text {cor })} \times \text { Prev } \times \text { } \Sigma \mathrm{BL} \times \mathrm{PV}_{[0]}
$$

$\mathrm{P}=$ The number of economic losses that have been corrected

$\mathrm{f}_{(\text {cor })} \quad=$ Correction factor $(2 \%$ and $9 \%)$

Prev = Underweight prevalence

$\Sigma \mathrm{BL}=$ Total births

$\mathrm{PV}_{[0]}=$ Economic potential of children at 0 years old

\section{Research Assumption}

This research used several assumptions. These assumptions were used so that the research results can be generally accepted. The assumptions used in this research were: (1) underweight toddlers will

\begin{tabular}{|c|c|c|c|}
\hline No. & Province & $\begin{array}{c}\text { Underweight } \\
\text { Prevalence (\%)* }\end{array}$ & $\begin{array}{c}\text { Number of } \\
\text { Underweight } \\
\text { Toddlers }\end{array}$ \\
\hline 1. & Aceh & 40.1 & 224,953 \\
\hline 2. & North Sumatera & 44.9 & 148,922 \\
\hline 3. & West Sumatera & 38.7 & 49,304 \\
\hline 4. & Riau & 36.9 & 445,088 \\
\hline 5. & Jambi & 39.2 & 70,837 \\
\hline 6. & South Sumatera & 37.4 & 100,627 \\
\hline 7. & Bengkulu & 39.9 & 371,003 \\
\hline 8. & Lampung & 41.2 & 44,648 \\
\hline 9. & $\begin{array}{l}\text { Bangka Belitung } \\
\text { Archipelago }\end{array}$ & 26.8 & 86,962 \\
\hline 10. & $\begin{array}{l}\text { Riau } \\
\text { Archipelago }\end{array}$ & 29.0 & $1,259,355$ \\
\hline 11. & $\begin{array}{l}\text { Special Capital } \\
\text { District of } \\
\text { Jakarta }\end{array}$ & 29.9 & 831,790 \\
\hline 12. & East Java & 36.0 & $1,076,508$ \\
\hline 13. & Central Java & 36.1 & 177,550 \\
\hline 14. & $\begin{array}{l}\text { Special Region } \\
\text { of Yogyakarta }\end{array}$ & 25.6 & 104,335 \\
\hline 15. & East Java & 35.7 & 87,311 \\
\hline 16. & Banten & 34.2 & 139,127 \\
\hline 17. & Bali & 33.0 & 70,984 \\
\hline 18. & $\begin{array}{l}\text { West Nusa } \\
\text { Tenggara }\end{array}$ & 45.0 & 360,520 \\
\hline 19. & $\begin{array}{l}\text { East Nusa } \\
\text { Tenggara }\end{array}$ & 51.6 & 100,853 \\
\hline 20. & $\begin{array}{l}\text { West } \\
\text { Kalimantan }\end{array}$ & 38.5 & 52,299 \\
\hline 21. & $\begin{array}{l}\text { Central } \\
\text { Kalimantan }\end{array}$ & 40.6 & 206,644 \\
\hline 22. & $\begin{array}{l}\text { South } \\
\text { Kalimantan }\end{array}$ & 43.2 & 266,735 \\
\hline 23. & East Kalimantan & 30.3 & 99,601 \\
\hline 24. & North Sulawesi & 37.8 & 35,032 \\
\hline 25. & Central Sulawesi & 41.8 & 292,043 \\
\hline 26. & South Sulawesi & 41.4 & 58,375 \\
\hline 27. & $\begin{array}{l}\text { Southeast } \\
\text { Sulawesi }\end{array}$ & 41.0 & 341,484 \\
\hline 28. & Gorontalo & 39.7 & 116,609 \\
\hline 29. & West Sulawesi & 46.7 & 137,384 \\
\hline 30. & Maluku & 40.4 & 84,233 \\
\hline 31. & North Maluku & 41.1 & 330,152 \\
\hline 32. & West Papua & 42.7 & 233,600 \\
\hline 33. & Papua & 40.5 & 637,668 \\
\hline & Indonesia & 38.4 & $9,211,446$ \\
\hline
\end{tabular}
experience a reduced productivity by $2-9 \%$ based on Horton (Horton, 1999); (2) Salaries/wages received in all business sectors are similar; (3) the data used have similar subject characteristics; (4) the discount rate used was $5 \%$.
Table 1. Prevalence of Underweight Toddlers in Indonesia in 2013

*Results of microdata processing (Riskesdas 2013) by the researcher.

Source: CSA / BPS 2013. Health Research and Development Agencies in 2013 


\section{RESULTS AND DISCUSSION}

\section{Prevalence and Risk Factor of Underweight in Toddler}

The problem of malnutrition is still a major concern throughout the world, including Indonesia.

Poverty, food insecurity, infectious diseases, and sanitation are some of the risk factors that cause malnutrition. Below is the prevalence of underweight problems shown in Table 1.

Table 1. shows the highest prevalence of underweight was found in the East Nusa Tenggara Province (51.6\%) while the lowest was Special Region of Yogyakarta (25.6\%).

Table 2. Estimated Potential Economic Losses due to Underweight

\begin{tabular}{|c|c|c|c|c|c|}
\hline \multirow{2}{*}{ No. } & \multirow{2}{*}{ Province } & \multirow{2}{*}{$\begin{array}{c}2 \% \\
\text { (billion IDR) }\end{array}$} & \multirow{2}{*}{$\begin{array}{c}9 \% \\
\text { (billion IDR) }\end{array}$} & \multicolumn{2}{|c|}{ \%GRDP } \\
\hline & & & & $2 \%$ & $9 \%$ \\
\hline 1. & Aceh & 45 & 202 & 0.05 & 0.23 \\
\hline 2. & North Sumatera & 54 & 242 & 0.01 & 0.06 \\
\hline 3. & West Sumatera & 50 & 224 & 0.04 & 0.18 \\
\hline 4. & Riau & 65 & 292 & 0.02 & 0.09 \\
\hline 5. & Jambi & 79 & 357 & 0.11 & 0.48 \\
\hline 6. & South Sumatera & 231 & 1,040 & 0.13 & 0.58 \\
\hline 7. & Bengkulu & 26 & 115 & 0.09 & 0.42 \\
\hline 8 & Lampung & 77 & 346 & 0.05 & 0.21 \\
\hline 9 & Bangka Belitung Archipelago & 5 & 24 & 0.01 & 0.06 \\
\hline 10 & Riau Archipelago & 3 & 11 & 0.00 & 0.01 \\
\hline 11 & Special Capital District of Jakarta & 22 & 97 & 0.00 & 0.01 \\
\hline 12 & East Java & 364 & 1,639 & 0.04 & 0.16 \\
\hline 13 & Central Java & 435 & 1,956 & 0.08 & 0.35 \\
\hline 14 & Special Region of Yogyakarta & 23 & 102 & 0.04 & 0.16 \\
\hline 15 & East Java & 339 & 1,527 & 0.03 & 0.13 \\
\hline 16 & Banten & 25 & 114 & 0.01 & 0.05 \\
\hline 17 & Bali & 73 & 328 & 0.08 & 0.35 \\
\hline 18 & West Nusa Tenggara & 74 & 332 & 0.13 & 0.59 \\
\hline 19 & East Nusa Tenggara & 61 & 272 & 0.15 & 0.67 \\
\hline 20 & West Kalimantan & 87 & 391 & 0.10 & 0.46 \\
\hline 21 & Central Kalimantan & 23 & 105 & 0.04 & 0.17 \\
\hline 22 & South Kalimantan & 21 & 97 & 0.03 & 0.12 \\
\hline 23 & East Kalimantan & 148 & 664 & 0.05 & 0.23 \\
\hline 24 & North Sulawesi & 41 & 187 & 0.08 & 0.35 \\
\hline 25 & Central Sulawesi & 5 & 23 & 0.01 & 0.04 \\
\hline 26 & South Sulawesi & 257 & 1,156 & 0.14 & 0.63 \\
\hline 27 & Southeast Sulawesi & 68 & 306 & 0.17 & 0.75 \\
\hline 28 & Gorontalo & 22 & 97 & 0.18 & 0.83 \\
\hline 29 & West Sulawesi & 155 & 697 & 0.96 & 4.31 \\
\hline 30 & Maluku & 17 & 77 & 0.13 & 0.58 \\
\hline 31 & North Maluku & 151 & 681 & 1.96 & 8.82 \\
\hline 32 & West Papua & - & - & - & - \\
\hline 33 & Papua & 10 & 46 & 0.01 & 0.05 \\
\hline \multicolumn{2}{|r|}{ Indonesia } & 3,054 & 13,746 & 0.04 & 0.16 \\
\hline
\end{tabular}

Note: GRDP at current prices without oil and gas

Source: Results of data processing and researcher calculation 2013. 


\section{Estimated Potential Economic Losses due to Underweight}

Table 2 shows the value of economic losses due to decreased productivity caused by problems of underweight toddlers in Indonesia.

\section{Prevalence and Risk Factor of Underweight in Toddler}

The above prevalence data shows that the highest underweight problem was in East Nusa Tenggara. West Sulawesi. West Nusa Tenggara. North Sumatera, and South Kalimantan. Various problems arising from malnutrition include the high rate of Low Birth Weight (LBW) toddler which result from Protein Energy Deficiency (PDE) during pregnancy. This results in physical, mental and intelligence disorders in children, and also increases the risk of toddler born with a lack of iron. Lack of iron in toddler can cause disruption of brain cells development which then can reduce children's IQ by $10 \%$. In addition, malnourished children are prone to diabetes and coronary heart disease.

The worst result is death at a very early age. The incidence of malnutrition needs to be monitored and detected early through intensification of growth monitoring and identification of risk factors closely related to extraordinary events of nutrition such as measles and diarrhea through surveillance activities. Additionally, the main thing that needs to be considered is the parenting skills of parents in choosing and feeding children. In order to achieve the expectation and lead to positive results, a mother needs to obtain information regarding food and family nutrition. Cases of toddler mortality due to malnutrition are repeated massively occurred with an almost evenly distributed area in Indonesia. From the monitoring conducted the case findings occurred after the children entering the critical phase. Meanwhile, intensive care is only carried out after these children are completely helpless. This shows that before these children are in the critical phase, the attention towards their rights to live and their best interests are ignored.

According to Alderman (2010), in his notes, there were huge economic consequences of malnutrition in all its form, "economic return to prevent malnutrition is equivalent to investments which are generally considered as the heart of economic development strategies." The body of evidence supporting this view that has accumulated over recent years was substantial and robust. For example. FAO had calculated that an annual investment of US\$1.2 billion just in improving the micronutrient supply globally through a) supplementation. b) food fortification and/or c) biofortification of staple crops would result in "better health, fewer deaths and increased future earnings" of up to US\$15.3 billion per year: a 13to-1 benefit-to-cost ratio (Global Panel. 2015).

\section{Estimated Potential Economic Losses due to Underweight.}

The average potential economic losses in 32 provinces in Indonesia were around IDR 93 billion - IDR 417 billion, which seen from the Gross Regional Domestic Product (GRDP) percentage. The economic loss due to decrease in productivity amounted to $2 \%$ and $9 \%$ or about $0.1-0.7 \%$ of the average GRDP for each Provinces in Indonesia. The highest range of potential economic loss due to underweight was found in Central Java Province. The decrease on productivity (both on $2 \%$ and $9 \%$ productivity) would be implicated on the derivation of GRDP.

Unresolved underweight problem among toddler would potentially make the National GDP loss up to IDR 3,054 billion if the productivity decreased as much as $2 \%$. This amount of detriment will soar up to 6 times (IDR 13,746 billion) if the productivity alight up to $9 \%$. This results of potential economic losses due to underweight toddlers were not the total effect of potential economic losses due to various condition that may occur in underweight toddlers, such as no calculation of treatment costs caused by infection disease in underweight toddlers who have low immunity as well as early death costs which is caused by non-communicable diseases (NCD) or other diseases caused by underweight. It was implied that the estimated economic loss in the study might underestimate the true economic loss due to underweight. However, this study is still important to capture the economic loss of underweight.

Malnutrition is a major problem experienced by children in the various part of the world, which 
is harmful for both children and the country. This problem of malnutrition becomes a burden for a country, especially for poor and developing countries. A poor country can have a high burden up to $3 \%$ of the country's gross income and it is estimated that malnutrition in all its forms could cost society up to US\$3.5 trillion per year (Khan et al., 2007; UNICEF, 2018).

Unfortunately, the studies regarding the estimated economic losses due to Protein Energy Deficiency (PED) is limited. The existing results of research by Aries and Martianto (2006) showed that the province with the highest potential economic losses due to PED in toddlers was Special Capital District of Jakarta, while the lowest was found in North Maluku. Nationally, the amount of estimated potential economic losses due to malnutrition (PED) in toddlers was ranging between $0.27-1.21 \%$ of Indonesia's GDP (worth IDR 4.24 trillion - IDR 19.08 trillion).

The report from The economic costs of disease-related malnutrition showed that India's losses were large in part because the Country had the largest number of wasted came to almost $€ 2$ billion (US\$2.23), which was $2 \%$ higher than the total Dutch national health expenditure in that year (Freijer et al., 2013). Similarly. a more recent study in England documented that the added spending on medical and social care associated with malnutrition in 2011-12 was almost $£ 20$ billion, or more than $15 \%$ of total public expenditure (Elia, 2015). The impact of the indicators of malnutrition analyzed represent a burden to the national economy of Cambodia estimated at 266 million USD annually ( $1.7 \%$ of GDP). The impact of the indicators of malnutrition analyzed in the report represents a burden to the national economy of Cambodia estimated at more than 260 million USD annually. This amount represents $1.7 \%$ of the estimated 2013 Gross Domestic Product (GDP) from the Ministry of Economy and Finance (15.8 billion USD) (Pfanner et al., 2016).

According to the report by Food and Nutrition Research Institute of the Department of Science and Technology (FNRI-DOST) by Save the Children Philippine (2016), as many as 48,597 students from the Philippines repeated a grade in 2013 and $15 \%$ of the repeater population is due to malnutrition. The cost for this problem was around $\mathrm{PhP} 1.23$ billion (1.23 billion pesos) to cover this repetition and keep students in school. Of the total cost. $43 \%$ was imposed to the family while the rest was covered by the public service system. The declining educational attainment among undernourished workers as children was translated into $\mathrm{PhP} 166.6$ billion lost income. Premature death reduces national productivity with an additional $\mathrm{PhP} 160$ billion with the estimated 838,000 deaths occurred before five years old among children who would be part of the 2013 working age. The root problems of malnutrition are poverty, low education levels, and low access to health care centers (Khan et al., 2007). The increased morbidity and mortality have a broad economic impact on the family and the country's health system.

\section{CONCLUSION}

The amount of national potential economic losses due to underweight based on toddler underweight prevalence in 2013 is IDR 3,054 billion - IDR 13,746 billion or $0.04-0.2 \%$ of Indonesia's total GDP. The highest range of potential economic losses due to underweight is IDR 435 billion - IDR 1956 billion in Central Java Province which 2\% decreased productivity caused $0.08 \%$ decrease on its province's GRDP and $0.3 \%$ decrease on $9 \%$ decreased productivity. The lowest range of potential economic losses is IDR 3 billion - IDR 11 billion in Riau Archipelago Province which $2 \%$ decreased productivity caused $0.03 \%$ decrease on its province's GRDP and $0.01 \%$ decrease on $9 \%$ decreased productivity.

\section{RECOMMENDATION}

The further study is recommended because the study used secondary datas that could not be verified. Moreover, the used data was derived from a cross-sectional study design. An extension investigation to account the life expectancy or early death caused by malnutrition is needed.

\section{ACKNOWLEDGEMENT}

The author expresses the gratitude to the Kopertis Region V Yogyakarta for the research funding. The author also thanked to the Health 
Research and Development Agency the Central Statistics Agency, and the Indonesian Ministry of Health for providing the research data.

\section{REFERENCES}

African Union Commission \& World Food Programme. (2015). The Cost of Hunger in Malawi: Social and Economic Impact of Child Undernutrition in Malawi. Report. Implications on National Development and Vision 2020. Retrieved from http://www.mw.one.un. org / wpcontent/uploads/2015/05/COHA-LaunchFull-Report-Malawi.compressed. pdf.

Alderman, H. (2010). The economic cost of a poor start to life. Journal of Developmental Origins of Health and Disease. 1 (1): 19-25.

Aries, M., \& Martianto, D. (2006). Estimasi kerugian ekonomi akibat status gizi buruk dan biaya penanggulangannya pada balita di berbagai provinsi di Indonesia. Jurnal Gizi dan Pangan. 1(2): 26-33.

Azwar, A. (2004). Kecenderungan masalah gizi dan tantangan di masa datang. Jakarta 27 September 2004, presented at Pertemuan Advokasi Program Perbaikan Gizi Menuju Keluarga Sadar Gizi: Jakarta.

BAPPENAS, Badan Perencanaan Pembangunan Nasional. (2019). Rencana Pembangunan Jangka Menengah Nasional IV 2020-2024. Jakarta (ID): Badan PPN/Bappenas.

BPS, Badan Pusat Statistik. 2013. Keadaan Pekerja Di Indonesia November 2013. Jakarta (ID): Badan Pusat Statistik Republik Indonesia.

Badan Penelitian dan Pengembangan Kesehatan. (2013). Laporan Hasil Riset Kesehatan Dasar Indonesia Tahun 2013. Jakarta(ID): Kementerian Kesehatan Republik Indonesia.

Baker-Henningham, H., \& Grantham-McGregor, S. (2009). Gizi dan Perkembangan Anak. In: Gibney MJ. Margetts BM. Kearney JM dan Arab L(Eds). Gizi Kesehatan Masyarakat. Jakarta (ID): EGC.

Elia, M. (2015). The cost of malnutrition in England and potential cost savings from nutritional interventions. National Institute for Health Research. Published on website by BAPEN and National Institute Health Research Southampton Biomedical Research Centre. ISBN: 978-1899467-03-3. Retrieved from : https://www. bapen. org.uk/pdfs/economic-report-short.pdf. Freijer, K., Tan S.S., Koopmanschap M.A., Meijers,
J.M.M., Halfens R.J.G., \& Nuijten, M.J.C. (2013). The economic costs of disease related malnutrition. Clinical Nutrition. 32(1): 136-141. doi: 10.1016/j.clnu.2012.06.009

Frontier economics. (2017). Short Changed: The human and Economic Cost of Child Undernutrition in Papua New Guinea. June. Save the Children. Available from: https://www. savethechildren.org.au/getmedia/565e03526a4f-46c1-bea8-331acd1 b4c8c/png-nutritionreport.pdf.aspx.

Global Panel. (2015). Biofortifiation: An Agricultural Investment for Nutrition. Policy Brief No. 1. London. UK: Global Panel on Agriculture and Food Systems for Nutrition. Retrieved from: https://glopan.org/sites/default/ files/document-files/Biofortification_Policy_ Brief_FINAL.pdf

Hadi, H. (2005). Beban Ganda Masalah Gizi dan Implikasinya terhadap Kebijakan Pembangunan Nasional. Pidato Pengukuhan Guru Besar Yogyakarta: Universitas Gadjah Mada.

Horton, S. (1999). Opportunities for investments in nutrition in low-income Asia. Asian Development Review. 17: 246-273. Progress. New York(US): Oxford University Press.

Kalsum, U. (2013). Selected risk factors related to underweight children aged 24-59 months in Jambi province. Indonesia. Health Science Journal of Indonesia. 4(2): 78-82. Retrieved from http://ejournal.litbang.depkes.go.id/index. php/HSJ//article/view/3436.

Kalsum, U., \& Jahari, A.B. (2015). Strategi menurunkan prevalensi gizi kurang pada balita di Provinsi Jambi. JMJ. 3(1): 45-59.

Kemenkes RI, Kementerian Kesehatan Republik Indonesia. (2014). Laporan Bulanan Data Sosial Ekonomi. Edisi 55 Desember 2014. Jakarta (ID): Badan Pusat Statistik Republik Indonesia.

Kemenkes RI, Kementerian Kesehatan Republik Indonesia. (2013). Kegiatan Pelayanan Kebidanan di RS per Provinsi di Indonesia. Jakarta: Sistem Informasi Rumah Sakit Kementerian Kesehatan RI.

Khan, A.A., Bano, N., \& Salam, A. (2007). Child Malnutrition in South Asia. A comparative Perspective. South Asian Survey. 14(1): 129145.

Pfanner, R.M., Silo, S., Laillou, A., Wieringa, F., Hong, R., Hong, R., Poirot, E., \& Bagriansky,s J. (2016). The Economic Burden of Malnutrition 
in Pregnant Women and Children under 5 Years of Age in Cambodia. Journal Nutrients. (8) 292, 1-14. doi:10.3390/nu8050292.

UNICEF. United Nations Children's Fund. (2013). Improving Child Nutrition: The Achievable Imperative for Global. Retrieved from https:// data.unicef.org/resources/improving-childnutrition-the-achievable-imperative-for-globalprogress/
UNICEF. United Nations Children's Fund. (2018). Global Nutrition Report reveals malnutrition is unacceptably high and affects every country in the world but there is also an unprecedented opportunity to end it. Retrieved from https://www.unicef.org/pressreleases/2018-global-nutrition-report-revealsmalnutrition-unacceptably-high-and-affects 